Contents List available at RAZI Publishing

Pakistan Journal of Geology (PJG)

Journal Homepage: http://www.razipublishing.com/journals/pakistanjournal-of-geology-pjg/

\title{
Microfacies and Diagenetic Analysis of Chorgali Carbonates, Chorgali Pass, Khair-E-Murat Range: Implications for Hydrocarbon Reservoir Characterization
}

\author{
Muhammad Zawar Khan, Zain ur Rahman , Zeeshan Khattak ${ }^{1}$, Muhammad Ishfaque ${ }^{2}$ \\ Department of Earth \& Environmental Sciences, Bahria University Islamabad, Pakistan. Institute of Geology, The university of Azad \\ Jammu and Kashmir, Muzaffarabad, Pakistan. *Corresponding Author: Rajayasinkhan@gmail.com
}

This is an open access article distributed under the Creative Commons Attribution License, which permits unrestricted use, distribution, and reproduction in any medium, provided the original work is properly cited

\section{ARTICLE DETAILS}

Article history:

Received 24 October 2016

Accepted 7 December 2016

Available online 3 January 2017

Keywords:

depositional, stratigraphic section, microfacies,

Wackestone-Packstone,

stylolitization, neomorphism

\section{ABSTRACT}

In this study integrated approaches combining field study, petrographic analysis and petrophysical analysis has been used to infer the depositional and diagenetic effects on reservoir characteristics. The exposed stratigraphic section of Chorgali Formation at its type locality was logged, sampled and petrophysical analysis of well log data from Fimkassar-02 were carried out. Three microfacies recognized from petrographic studies are: Bioclastic Wackestone-Packstone Microfacies, Mixed Bioclastuc Wackestone-Packstone Microfacies and Larger Foraminiferal Wackestone-Packstone Microfacies. The depositional texture and faunal association suggested that the microfacies represents deposition in a low energy, distally steepened ramp type of setting. Due to the deposition in low energy environment the ratio of lime mud is more than bioclasts as a result the primary pore spaces in the formation are negligible. The analysis further showed that the carbonates of Chorgali Formation was also subjected to various diagenetic changes, mainly showing the compaction, stylolitization, aragonite to calcite transformation (neomorphism), tectonically induced fracturing and calcite veins passing from marine diagenesis to meteoric diagenesis through burial diagenesis. Fracturing due to later tectonic deformation have had a major influence on porosity generation and in some cases fracturing and stylolites together have had an important effect on permeability values. The petrophysical analysis shows that the Eocene Chorgali Formation is very good reservoir with average hydrocarbon saturation of $80 \%$.

\section{Introduction}

The Chorgali Pass, the type locality of Chorgali Formation is located in the Khair-e-Murat range, at latitude. $33^{\circ} 26^{\prime} 30^{\prime \prime} \mathrm{N}$, longitude. $72^{\circ} 41^{\prime}$ $06^{\prime \prime}$ E, in the region of Northern Potwar Deformed Zone (NPDZ). The NPDZ is the intensely deformed northern part of Potwar Basin, and is mainly characterized by complex and tight folds, which are trending east-west and are overturned to south at sheared by step-angle faults (Baker, 1987). The area is bounded by Soan Syncline in South and Main Boundary Thrust (MBT) in north (Fig. 2). The area is reachable from al sides and main roads connecting to the other parts of country. It lies 55 $\mathrm{km}$ SW of the Islamabad and $190 \mathrm{~km}$ from Peshawar (Fig. 1). The Chorgali Formation at Chorgali Pass area can be divided into two units; the dolomitic limestone and shale in lower part and shale with one thick bed of limestone and a bed of nodular argillaceous limestone near the top in the upper part (Shah, 1977). The Chorgali Formation is acting as reservoir in Dakhni, Fimkassar, Turkwal, Pindori, Dhurnal, Chak Naurang, Joyamir, Adhi and Balkassar fields. In present work the petrophysical analysis of Fimkassar Oil Fields has been carried out as an integrated approach to understand the reservoir characteristics of Chorgali Formation. Fimkassar oil fields is located at latitude. $33^{\circ} 04^{\prime}$ $56^{\prime \prime} \mathrm{N}$, longitude $72^{\circ} 57^{\prime} 18^{\prime \prime} \mathrm{E}$.

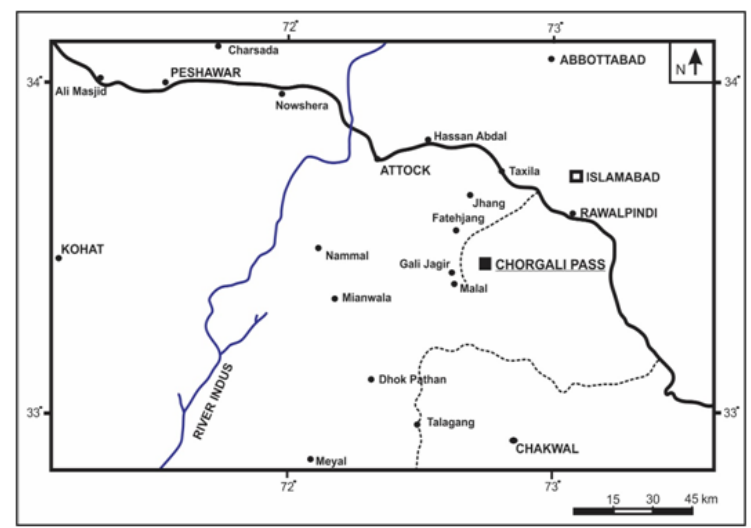

Fig. 1 Location map of study area (modified from Atlas of Pakistan). The objective of present study was to analyse the effect of deposition on reservoir characteristics of the Chorgali carbonates and to infer the major diagenetic (early and late) features controlling reservoir performance.

\footnotetext{
2.Methodology

The detailed field work of Chorgali Pass in Khair-e-Murat Range was carried out. Different sedimentary and sedimentological features were studied along the collection of samples. A total of 6 samples were collected for further petrographic analysis. For studying the detailed petrography, a total of 12 thin sections $(2$ from each sample) were prepared by using the established thin section technique (Flügel, 2004). The initial study of thin sections for petrographic analysis were carried out at Petrographic Lab in Department of Earth and Environmental Sciences, Bahria University Islamabad. The photomicrographs were taken by using
} 
digital camera fitted Nikon Petrographic Microscope at the Hydrocarbon Development Institute of Pakistan (HDIP).

Petrographic study has been used as the major tool in the study for microfacies and diagenetic analysis. The classification scheme of Dunham (1962) has been used in this study, which is based on determination of percentage of bioclasts and micrite. The microfacies identified were compared with the standared Microfacies of Flugel (1982) and Wilson (1975). The depositional model presented is based on the interpreted microfacies and depth ranges of biota.

The effect of deposition and diagenetic processes on the reservoir characteristics of carbonates of Chorgali Formation and porosity percentage was estimated visually. Well log data of Fimkassar-02 was interpreted by using PRIZM (GeoGraphix Suite) for the reservoir characterization of Chorgali carbonates.

\section{Results}

\subsection{Field observations}

Chorgali outcrop is located in the eastern part of Khair-e-Murat Range next to the Khair-e-Murat Fault. The outcrop area displays an anticlinal structure. The samples for present study were collected along the northern limb of anticline and different sedimentological properties i.e. lithology, color, texture, fossils and sedimentary structures were noticed and lithological log was prepared (Fig. 7).

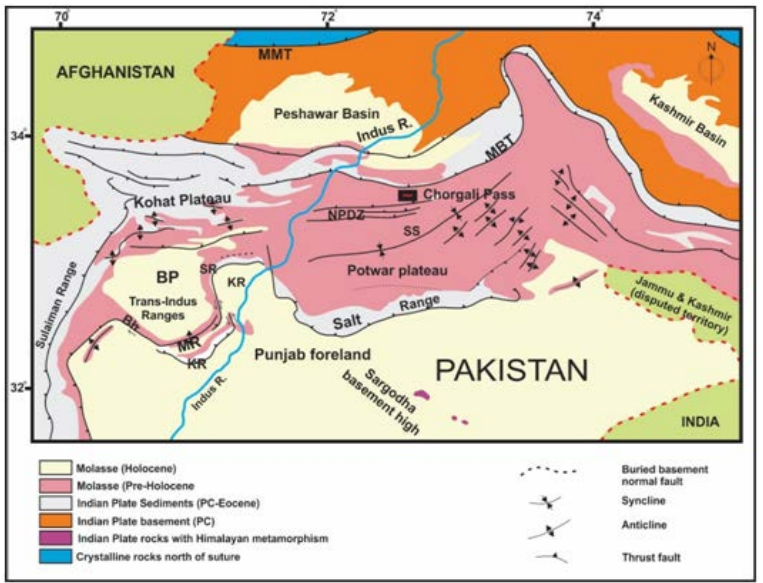

Fig. 2 Generalized structure of Kohat-Potwar geologic province redrawn from Kazmi and Rana, 1982; with inset box showing the location of study area. Features are abbreviated as: MMT=Main Mantle Thrust, MBT=Main Boundary Thrust, NPDZ= North Potwar Deformed Zone, KR=Kalabagh Reentrant, BP=Bannu Promontory, SR=Surghar Range, SS= Soan Syncline, KR=Khisor Range, MR=Marwat Range, Bh=Bhittani Range.

The lower part of formation is composed of partially dolomitized limestone ranging in color from white to light grey, weather to yellowish grey, medium hard, medium bedded with intercalated shale. The solution breccia in upper part is also well developed due to pressure solution and compaction (Fig. 3-A). The rocks are highly fractured but most of the small fractures are filled by calcite (Fig. 3-B). The fracturing in the rocks is vertical (Fig. 4-A) and also some algal laminations (Fig. 4-B) in the northern limb of anticline were observed in the field. The limestone at the base are highly fossiliferrous (Fig. 5-A) and also some cavities of eroded fossils (Fig. 5-B) and reworked fragments of limestone were observed. The upper contact of Chorgali Formation is conformable with Kuldana Formation (Fig. 6) is mainly composed of variegated shale with interbedded limestone, marl and rare gypsum bands.

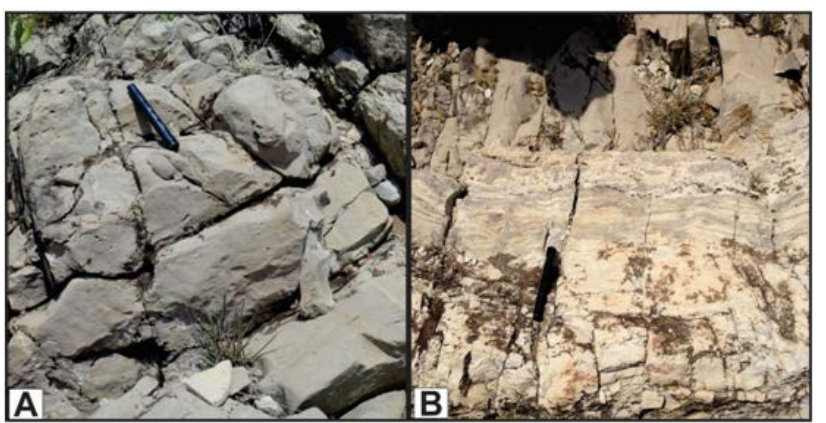

Fig. 4 (A) Photograph of fractures, vertical to the original bedding. (B) The algal laminations, horizontal with the original bedding.

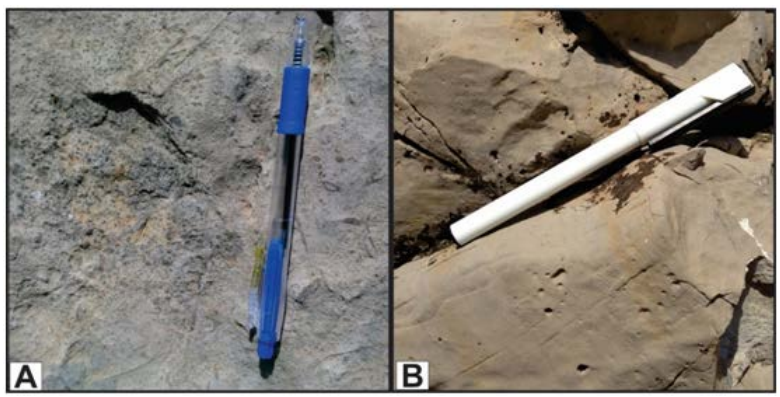

Fig. 5 (A) Photograph of fossiliferous limestone of Chorgali Formation. (B) The cavities, made due to erosion of fossils.

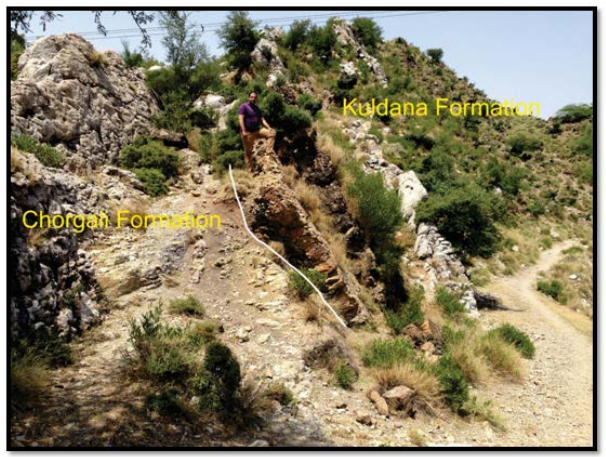

Fig. 6 Photograph of the contact between Chorgali Formation and overlying Kuldana Formation (See person standing in figure for scale).

\subsection{Microfacies Analysis}

The classification scheme of Dunham (1962) was used for microfacies analysis. The microfacies identified were compared with the standard microfacies of Flügel (1982) and Wilson (1975). Total three microfacies were identified on the basis of petrographic analysis of Chorgali carbonates. Details of each microfacie are described below.

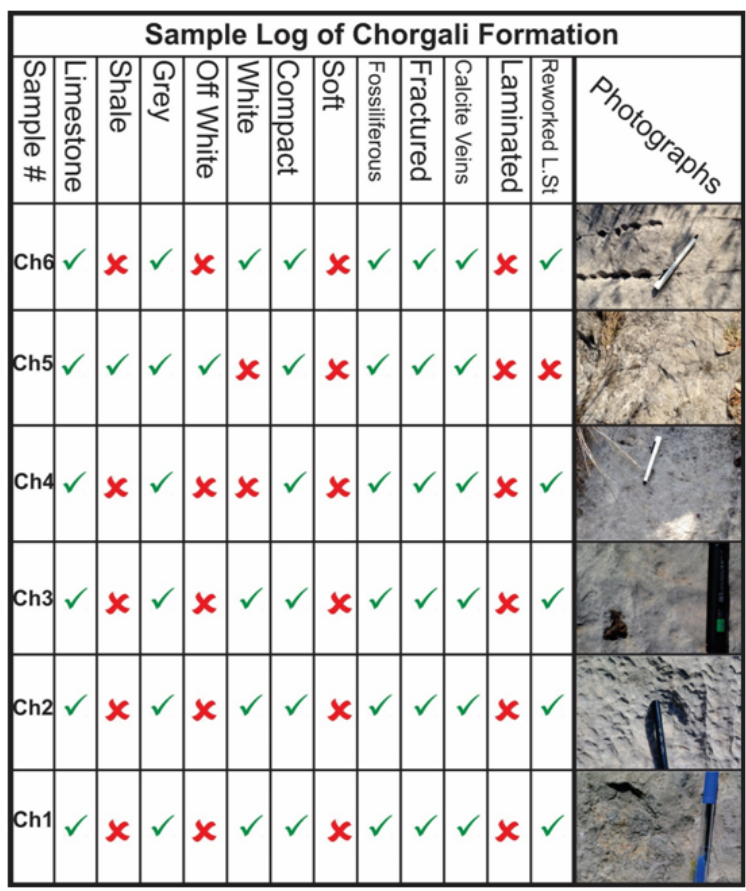

Fig. 7 Litholog of collected samples. 
3.2.1 Bioclastic wackestone-packstone microfacies (CF1)

In chorgali pass section CF 1 microfacies is represented by light grey colour, thin to medium bedded limestone. In thin section, CF 1 microfacies is characterized by a wack-packstone depositional textures. The biogenic content is well preserved and allochems abundance ranges from 30-60\%. The dominant allochems are larger benthic foraminifera i.e. Nummulites globulus, Nummulites mammilatus, Assilina granulosa, Assilina spinosa, Assilina laminosa, Lockhartia conditi and Lockhartia haimei (Fig. 8). Overall the bioclasts dominates and ranges in abundance from 30-60\%, with an average of $45 \%$. The average relative abundance of the biogenic grains is: Nummulites (8\%), Assilina (4\%), Lockhartia (2\%), Miscellanea (1\%) echinoderms $(1 \%)$, and algae (1\%).

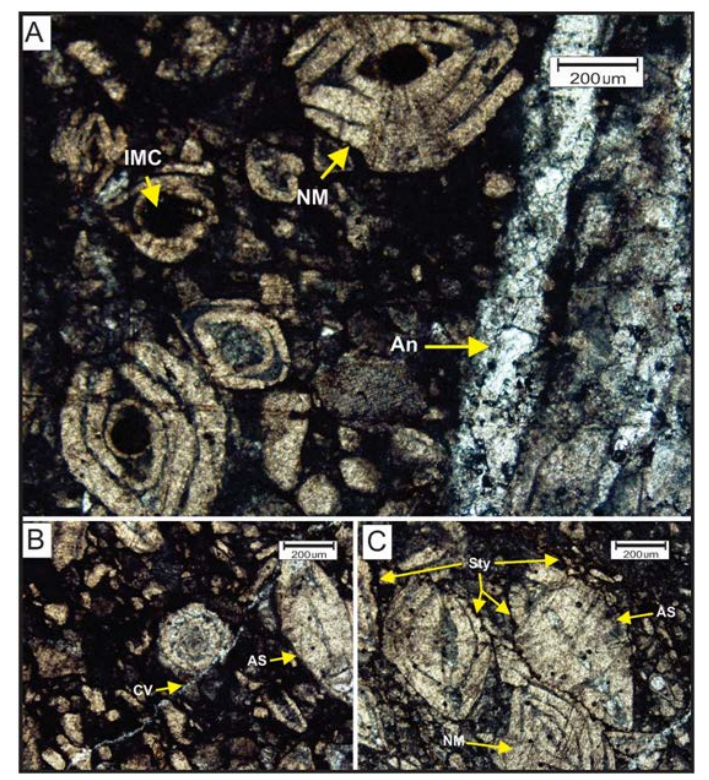

Fig. 8 Bioclastic Wackestone-Packstone Microfacies (CF 1): bioclasts of Nummulites (NM in A \& C) and Assilina (AS in B). Diagenetic fabric contains Anhydrite filling (An in A), calcite filled vein (CV in B), internel micritization (IMC in A) and stylolitic porosity (Sty in C). (Mag. $\mathrm{x} 40$ ).

3.2.2 Mixed Bioclastic wackestone-packstone microfacies (CF 2)

In the Chorgali pass section the CF 2 microfacies is represented by cream coloured medium bedded limestone. In thin section, the CF 2 microfacies is characterized by a wackestone-packstone depositional texture. CF 2 microfacies is rich in intraclasts ranging in abundance from $40-70 \%$, with an average of $50 \%$. The bioclasts are moderately preserved. The dominant allochems are larger benthic foraminifera i.e. Nummulites globulus, Nummulites mammilatus, Assilina granulosa and Alveolina indicatrixs (Fig. 9). The average relative abundance of the biogenic grains is: Nummulites (2\%), Assilina (1\%), Alveolina (1\%).

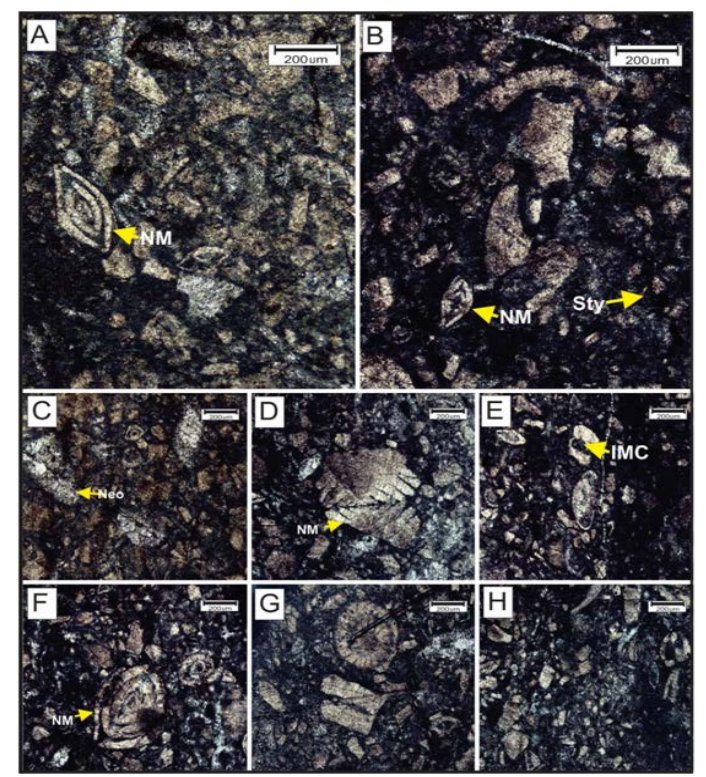

Fig. 9 Mixed Bioclastic Wackestone-Packstone Microfacies (CF 2): bioclasts of Nummulites (NM in A, B, D \& F). Diagenetic fabric contains Neomorphism (Neo in C), internel micritization (IMC in E) and stylolitic porosity (Sty in B). (Mag. x40)

\subsubsection{Larger foraminiferal wackestone-packstone microfacies (CF 3)}

In the Chorgali pass section the CF 4 microfacies is represented by the grey coloured thin to medium bedded limestone. In thin section, the CF 4 microfacies is characterized by a wackestone-packstone depositional texture. The biogenic content is well preserved having dominance of foraminiferal bioclasts with abundance ranges from $30-70 \%$, with an average of $45 \%$. The dominant allochems are larger benthic foraminifera i.e. Nummulites globulus, Nummulites mammilatus, Assilina granulosa, Assilina spinosa, Assilina laminosa, Lockhartia conditi, Lockhartia haimei and Alveolina indicatrixs (Fig. 10). Most of the foraminiferal bioclasts have a size range between $2 \mathrm{~mm}$ to $5 \mathrm{~mm}$. The micritic matrix dominates and its abundance ranges from 40 to 70 $\%$, with an average of $55 \%$. Some spar is related to the foraminiferal biodebris. The average relative abundance of the biogenic grains is: Nummulites (15\%), Assilina (20\%), Lockhartia (3\%) and Alveolina (2\%).

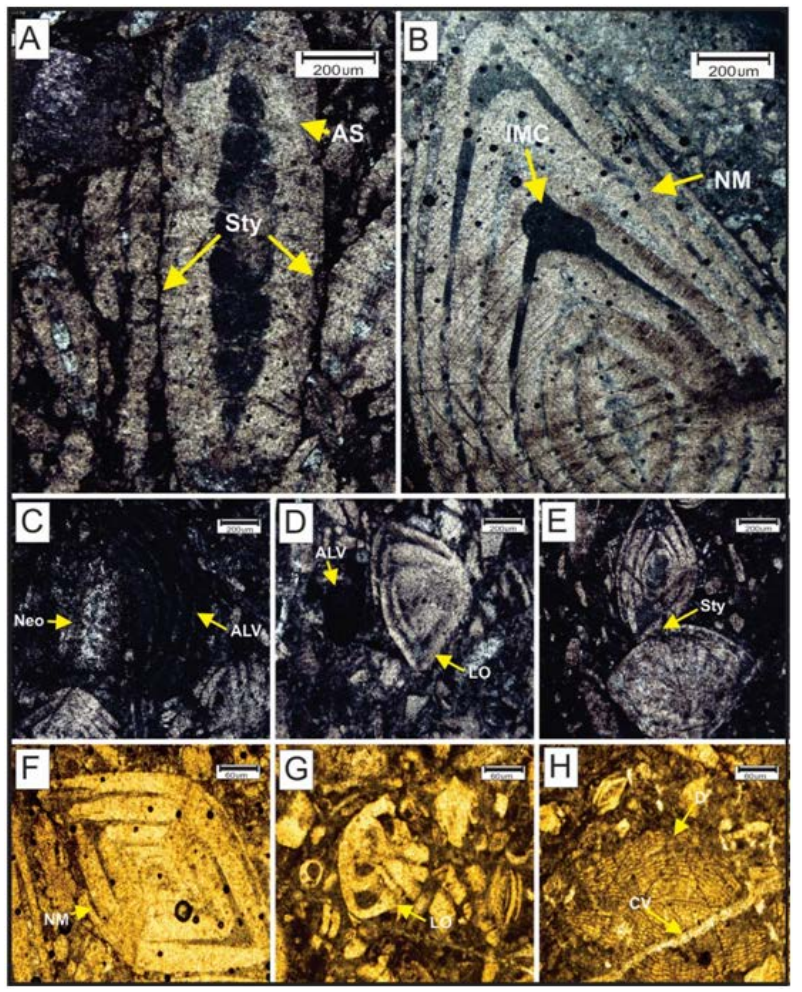

Fig. 10 Larger Foraminiferal Wackestone-Packstone Microfacies (CF 4): bioclasts of Nummulites (NM in B \& F) and Assilina (AS in A), Alveolina (ALV in D), Lockhartia (LO in D \& G), Discocyclina (D in H) Diagenetic fabric contains Neomorphism (Neo in C), calcite filled vein (CV in $\mathrm{H}$ ), internel micritization (IMC in B) and stylolitic porosity (Sty in A). (Mag. x40)

\subsection{Depositional environment}

The presence of diverse larger benthic foraminifera (Nummulites, Assilina and Lockhartia) and the micritic matrix show deposition of the CF 1 microfacies in low energy, below fair weather wave base in the inner shelf setting (Fig. 11). The microfacies is similar to SMF 8 of Wilson (1975) and Flügel (1982). The CF 2 microfacies is characterized by less diversity of faunal and floral constituents. The lime mud indicates low energy conditions of deposition. Based on textural characteristics and faunal content the microfacies are interpreted to represent deposition in middle shelf with open circulation at or just below the fair-weather wave base (Fig. 11). The microfacies are similar to SMF 9 of Wilson (1975) and Flügel (1982).

The CF 3 microfacies is characterized by the presence of lime mud with varying proportions of larger benthic foraminifera represented by Lockhartia, Nummulites, Alveolinids and Assilina, according to which the microfacies are interpreted to have been deposited in shallow, subtidal (below wave base) conditions on the distal inner shelf with no reworking (Fig. 11). The microfacies are similar to SMF 8 
smaller benthic, are present in very few amount (1-2\%). It shows that the carbonates of Chorgali Formation were deposited in shallow environment.

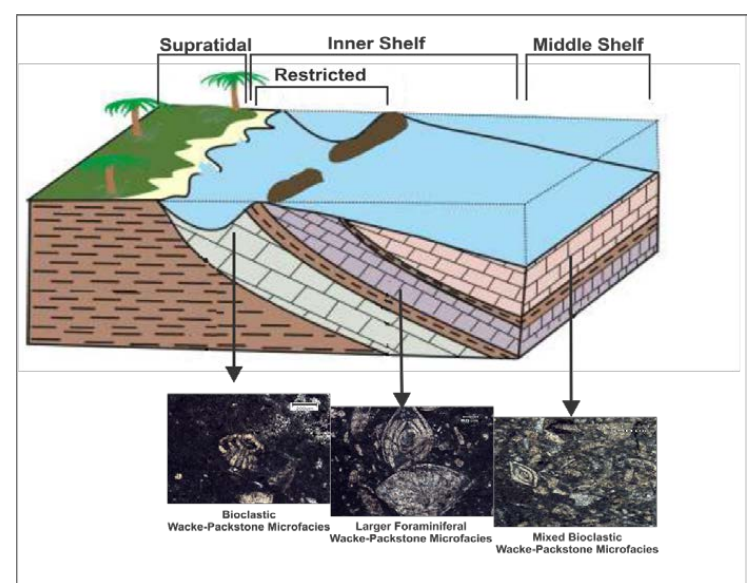

Fig. 11 Block diagram of the depositional environment of recognized microfacies of Chorgali carbonates.

\subsection{Diagenetic evolution}

The diagenetic fabric observed within Chorgali carbonates indicates that the formation is subjected to various post deposition processes, the diagenesis starts as soon as the rock get deposited and passes from marine diagenesis into burial to meteoric diagenesis. The Chorgali carbonates shows all three diagenetic environments; aragonite to calcite transformation, suggesting the marine diagenetic environment. The burial diagenesis can be shown by various stylolites and its associated seams, then in later stage the tectonic effect causes the fractures and its uplift to the surface for the meteoric diagenesis. A detail about observed diagenetic fabric is discussed below.

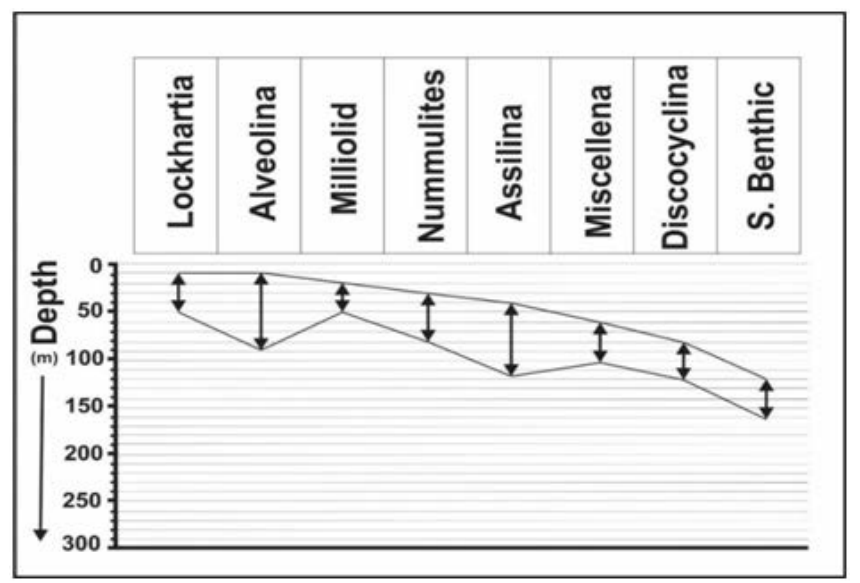

Fig. 12 Chart of the depth ranges of fossil assemblages in Chorgali carbonates (compiled From Treatise on Invertebrate Paleontology).

\subsubsection{Micritization}

The micritization is a process in which bioclasts are altered on the sea floor or just below water sediment interface. In Chorgali carbonates the grains are internally micritized and this phenomenon has been noticed occasionally (Fig. 13 A \& B).

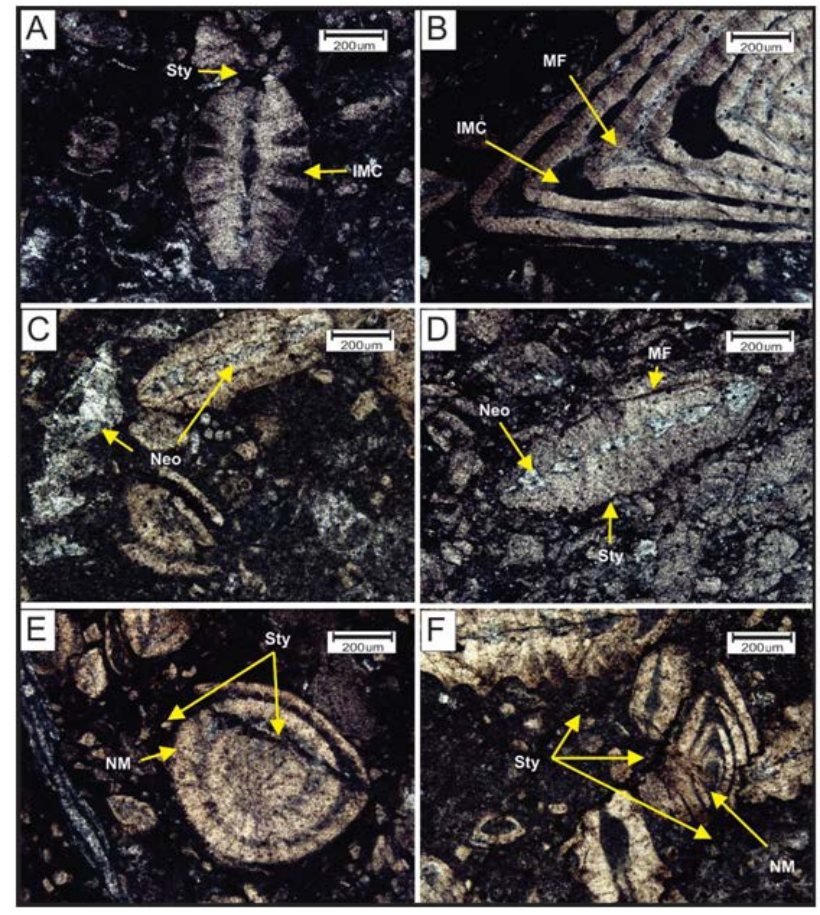

Fig. 13 Photomicropgraphs of different diagenetic fabrics in Chorgali carbonates, i.e. internal micritization of bioclasts (IMC in A \& B), presence of neomorphism (Neo in $\mathrm{C}$ ) and within the chambers of Assilina Neo in D), truncation of grain due to dissolution along stylolite (Sty in E) and set of stylolites around Nummilites grain (Sty in F), it is also showing truncation of grains along stylolite. (Mag. x40).

\subsection{Neomorphism}

The term Neomorphism is used for process of insitu replacement of one mineral by another of similar composition. In carbonate sedimentology, the term usually refers to aragonite to calcite transformation. The carbonates of Chorgali Formation in studied section shows the neomorphism along the micro fractures (Fig. $13 \mathrm{C}$ ) and also inside the shells of bioclasts (Fig. 13 D).
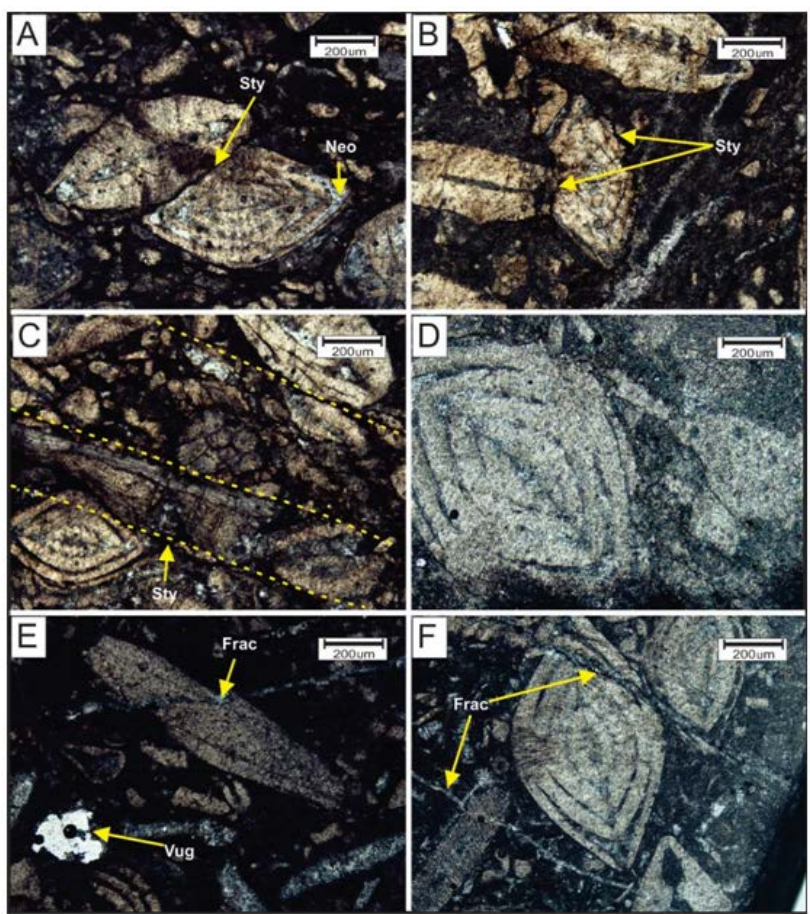

Fig. 14 Photomicrographs of diagenetic fabrics, i.e. interpenetration of grains due to compaction along stylolite (Sty in A) and plastic bending and truncation of grain along stylolite (Sty in B), alignment of grains due to compaction (C), partial dolomotization of Nummulities grain (D), calcite filled fracture along which grain has moved (Frac in E) and partially filled fracture also showing movement of grain (Frac in F). 


\subsubsection{Stylolites}

Stylolites are thin zones of discontinuity within rocks having undulate to zig-zag sutures. Stylolites result from pressure solution, dissolution of the limestone along planes as a result of overburden or tectonic pressure (Wanless, 1979). In Chorgali carbonates stylolites are low amplitude and are occasionally marked by the truncation of bioclasts (Fig. 13 E). At some places stylolites are forming network around the grain (Fig. $13 \mathrm{~F}$ ). The clay and iron residue also fills the stylolitic seams at some places.

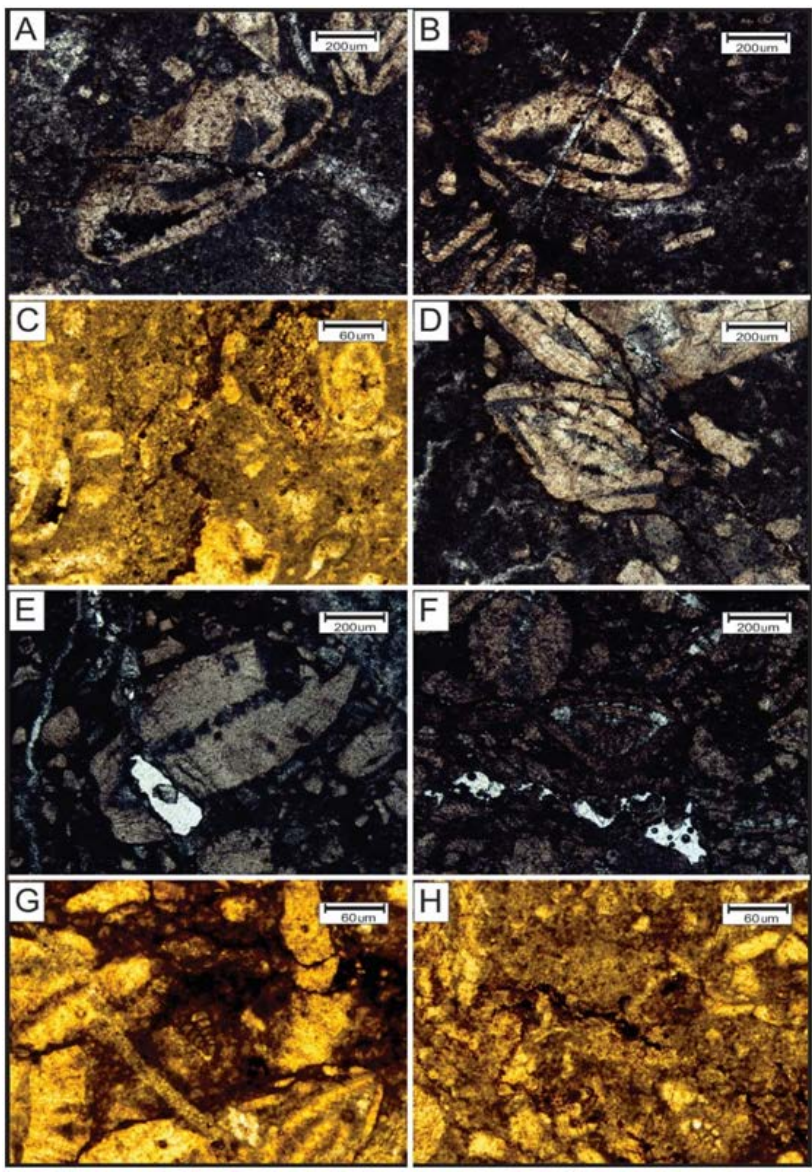

Fig. 15 Photomicrographs of different types of porosity in Chorgali carbonates i.e. fracture porosity (A\&B), stylolitic porosity (C\&D), vug porosity (E\&F) and moldic porosity (G\&H). (Mag. x40).

\subsubsection{Compaction}

The compaction refers to any process that decreases the bulk volume of rocks. This includes mechanical processes that decrease the bulk volume of single grains (grain deformation) or that cause closer packing of grains (reorientation) and pressure solution which decreases the volumes of grains and of cement minerals (Flugel, 1982). In the Chorgali carbonates compaction seem to have been responsible for some small fractures, which are partially to completely fill with calcite. Other features indicating compaction in Chorgali carbonates is interpenetration of grains (Fig 14 A), plastic bending (Fig 14 B) and alignment of the fragments (Fig 14 C).

\subsubsection{Dolomitization}

Dolomitization is the process which involves the conversion of aragonite and calcite into dolomite and may be early diagenetic or late diagenetic. Most of dolomite is a replacement of preexisting $\mathrm{CaCO} 3$, and there is a wide range of replacement fabrics developed. The Dolomite in the studied section of Chorgali carbonates is fabric retentive, medium grained and crystalline. Crystals are euhedral to subhedral (Fig. 14 D).

\subsubsection{Fractures}

The fractures in carbonate rocks may be originate from collapse related to solution, slumping or tectonic deformation (Choquette and Pray, 1970). In Chorgali carbonates most of the fractures are filled with sparry calcite, dolomite and anhydrite (Fig. 14 E). The breakage and movement of the grains along the fractures indicate that they are tectonically produced (Fig. 14 F) and microfracturing within the grains indicate that they are produced from the compaction of limestone. The tectonically induced fractures are important factors for the genesis of good permeability in carbonate rocks (Flugel, 1982).
3.5 Reservoir Characterization

The Reservoir characterization or reservoir quality includes two properties of rock, i.e., porosity and permeability and is a product of texture and composition of original sediment, which are modified by the diagenesis processes such as compaction, burial and deformation (Slatt, 2006). The Reservoir characterization can be determined by various techniques which includes; visual methods, laboratory techniques to Petrophysical measurements (Swati et al., 2014). In the present study, the effect of deposition and diagenetic processes on the reservoir characteristics of carbonates and porosity percentage of Chorgali Formation is estimated visually. Additionally Well log data of Fimkassar-02 was interpreted by using PRIZM (GeoGraphix Suite) for the reservoir characterization of Chorgali carbonates.

\subsubsection{Porosity}

Most of the Chorgali carbonates are tight in outcrop. Preserved primary porosity was not observed. All open pore spaces are secondary in origin. In most of the samples studied, microvugs and micromolds were noticed filled with calcite cement. The dominant porosity types of the Chorgali carbonates are fracture, vug, moldic and stylolitic porosity (Fig. 15). Presence of different types of porosity in studied samples along with total percentage is shown in table 2.

\subsubsection{Petrophysical analysis}

The reservoir zone of interest of 14 meter from $2902 \mathrm{~m}$ to $2916 \mathrm{~m}$ has been marked in Chorgali Formation, well Fimkassar-02. The following parameter are considered marking the suitable reservoir zone.

$\begin{array}{ll}\text { - } & \text { Borehole conditions } \\ \text { - } & \text { Low GR } \\ \text { - } & \text { Spegarative deflection between LLS and LLD } \\ & \text { Gas effect (the cross-over between NPHI and RHOB) }\end{array}$

The $14 \mathrm{~m}$ thick reservoir interval is comprised mainly of limestone with relatively high shale in upper part reaching $30 \%$ and $35 \%$ in lower part of the interval. The calculated sonic porosity for the interval is $12 \%$ whereas the effective porosity is $10.98 \%$.The zone is mainly saturated with hydrocarbon with $80.07 \%$ hydrocarbon and $19.83 \%$ water saturation. The petrophysical analysis shows that the Chorgali Formation is a potential reservoir.

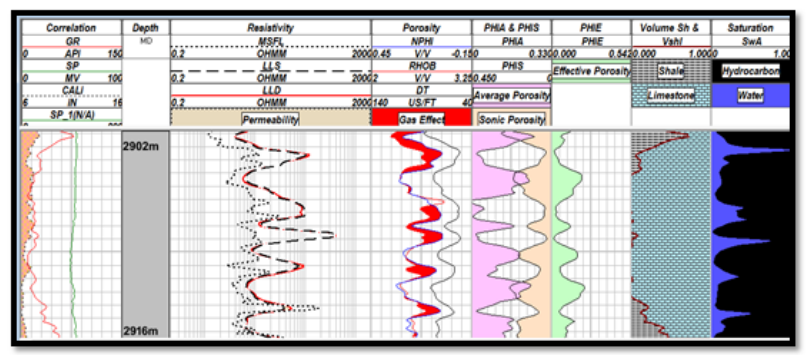

Fig. 16 Petrophysical analysis of Chorgali Formation in Fimkassar-02.

\section{Conclusions}

The Chorgali Pass section is type section of Chorgali Formation where it is mainly exposed and is composed of compact limestone with intercalated shales. Three microfacies have been identified in studied section of Chorgali carbonates on the basis of rock texture, grain types, biota and sedimentary structures. The microfacies are; Bioclastic WackestonePackstone, interpreted to have been deposited in low energy partially restricted environment; Mixed Bioclastic Wackestone-Packstone, interpreted to have been deposited in middle ramp environment; and Larger Foraminiferal Wackestone-Packstone, interpreted to have been deposited in distal inner ramp in low energy environment. On the basis of both microfacies diagnostic criteria and depth range of fossils, the Chorgali carbonates are interpreted to be deposited in shallowing upward sequence, on a shallow, partially restricted, low energy ramp type of setting. The depositional trends shows that carbonates of Chorgali Formation has been deposited in low energy environment due to which ratio of mud is more than bioclasts, in result the primary pore spaces in the formation are negligible. The presence of several diagenetic features indicate that the Chorgali carbonates in the study area has been subjected to various post depositional alterations including compaction, stylolitization, aragonite to calcite transformation, tectonically induced fracturing and development of calcite veins passing from marine diagenesis to meteoric diagenesis through burial diagenesis. In Chorgali carbonates the diagenesis has greatly affected the reservoir quality. Diagenetic fabrics from Chorgali carbonates shows that burial diagenesis has tended to reduce the reservoir quality hrough compaction, anhydrite 
precipitation, and carbonate cementation but on the other hand it has also generated the secondary porosity in result of stylolitization and fracturing. Fracturing due to later tectonic deformation have a major influence on porosity generation and in some cases fracturing and stylolites together have an important effect on permeability values. The petrophysical analysis shows that the Eocene Chorgali Formation can be a very good reservoir with average hydrocarbon saturation of $80.07 \%$.

\section{References}

[1] Baker, D.M., 1987: Balanced structural cross section of central Salt Range and Potwar Plateau of Pakistan, shortening and overthrust deformation, Oregen State University, Corvallis. M. S. thesis, $120 \mathrm{p}$.

[2] Choquette, P. W., Pray, L. C., 1970, Geologic nomenclature and classification of porosity in sedimentary carbonates: American Association of Petroleum Geologists Bulletin, 54: $207-250$

[3] Dunham, R. J., 1962. Classification of carbonate rocks according to depositional texture. In: W.E.Ham (E d.), Classification of carbonate rocks. American Association of Petroleum Geologist Memoir, 1: 108-121.

[4] Flügel, E., 1982. Microfacies Analysis of Limestone, Springer-Verlag, Berlin, 633.

[5] Flügel, E., 2004. Microfacies of Carbonate Rocks: Analysis, Interpretation and Application. Springer-Berlin, Heidelberg, New York.

[6] Kazmi, A. H., and Rana, R.A., 1982, Tectonic map of Pakistan: Geological Survey of Pakistan, scale: 1:2,000,000.

[7] Shah, S. M. I., 1977. Stratigraphy of Pakistan, Geological Survey of Pakistan Memoir, 1(12) -138.

[8] Slatt, R. M., 2006, Stratigraphic Reservoir Characterization for Petroleum Geologists, Geophysicists and Engineers: Hand book of Petroleum Exploration and Production, vol. 6, Elsevier.

[9] Swati, M. A. F., Haneef, M., Ahmad, S., Naveed, Y., Zeb, W., Akhtar, N., Owais, M., 2014. Diagenetic analysis of the Early Eocene Margala Hill limestone, Pakistan: A synthesis for thin section porosity. Journal of Himalayan Earth Sciences, 47(2): 49-61. 